\title{
Impacts of freshwater flushing on anammox community structure and activities in the New River Estuary, USA
}

\author{
Jessica A. Lisa ${ }^{1,2,4, *}$, Bongkeun Song ${ }^{1,2,4, *}$, Craig R. Tobias ${ }^{3}$, \\ Kimberley A. Duernberger ${ }^{2}$ \\ ${ }^{1}$ Department of Biology and Marine Biology, and ${ }^{2}$ Center for Marine Science, University of North Carolina Wilmington, \\ North Carolina 28403, USA \\ ${ }^{3}$ Department of Marine Sciences, University of Connecticut, Connecticut 06269, USA \\ ${ }^{4}$ Present address: Virginia Institute of Marine Science, College of William \& Mary, PO Box 1346, Gloucester Point, \\ Virginia 23062, USA
}

\begin{abstract}
Anaerobic ammonium oxidation (anammox) and denitrification are 2 microbial nitrogen removal processes that may play an important role in controlling the intensity and duration of estuarine and coastal eutrophication. Sediment communities in the New River Estuary, North Carolina were investigated to determine the dynamics of anammox activity and community structure in conjunction with environmental conditions. ${ }^{15} \mathrm{~N}$ tracer incubation experiments with sediment slurries were used to measure anammox and denitrification rates and estimate anammox contribution to total $\mathrm{N}_{2}$ production. Molecular analyses targeting the hydrazine oxidoreductase (hzo) gene were conducted to examine the structure of anammox communities and quantify the abundance of anammox bacteria in sediments. Potential anammox rates ranged from 0.02 to $1.4 \mathrm{nmol}$ $\mathrm{N}_{2} \mathrm{~g}^{-1} \mathrm{~h}^{-1}$, with the highest potential activities observed during winter and spring when the estuary received large doses of nitrogen from the watershed. Anammox contributed up to $14.1 \%$ of total $\mathrm{N}_{2}$ production in upstream estuarine sediments and abundance of anammox communities ranged from $1.55 \times 10^{2}$ to $2.59 \times 10^{5}$ hzo gene copies $\mathrm{g}^{-1}$ sediment. Both activities and abundance of anammox communities were correlated with percent sediment organics (\%organics) and the porewater concentrations of hydrogen sulfide. Based on hzo sequence analysis, anammox bacteria related to 'Candidatus Jettenia spp.' were widespread in estuarine sediments, which may be attributed to freshwater flushing and associated changes in environmental parameters as well as the geomorphology of the estuary. This is the first study to describe a dominance of 'Candidatus Jettenia spp.' in relation to \%organics and hydrogen sulfide in an estuarine ecosystem driven by meteorological forcing.
\end{abstract}

KEY WORDS: Anammox - 'Candidatus Jettenia spp.' · 'Candidatus Scalindua spp.' · hzo genes · New River Estuary

Resale or republication not permitted without written consent of the publisher

\section{INTRODUCTION}

Estuaries and coastal areas are highly productive ecosystems that serve as critical habitats for many marine organisms (Costanza et al. 1997). Anthropogenic activities and changes in coastal land use have resulted in excess nitrogen loading and eutrophication, which pose a threat to the ecological integrity of estuaries (Nixon 1995, Howarth et al. 2000). Two microbial nitrogen removal processes, anaerobic ammonium oxidation (anammox) and denitrification, may play a mitigating role in the intensity and dura- 
tion of estuarine eutrophication in response to high nitrogen loading. Both microbial processes occur simultaneously in estuarine sediments and are influenced by biogeochemical factors as well as ecosystem-scale controls, such as hydrological and geomorphological features of the system (Cornwell et al. 1999, Dalsgaard et al. 2005, Seitzinger et al. 2006).

Denitrification is an anaerobic respiratory process that reduces 2 molecules of nitrate $\left(\mathrm{NO}_{3}{ }^{-}\right)$to gaseous $\mathrm{N}_{2}$ and mainly occurs in the sediments and in the water column at the oxic-anoxic interface (Tuominen et al. 1998). A phylogenetically diverse group of organisms is capable of this respiratory process (Zumft 1997). Denitrification rates are generally influenced by labile organic carbon and $\mathrm{NO}_{3}{ }^{-}$availability, which can vary spatially and temporally within an estuary (Cornwell et al. 1999, Seitzinger et al. 2006).

Anammox, a more recently discovered pathway to $\mathrm{N}_{2}$ production, is a process that couples the reduction of 1 molecule of nitrite $\left(\mathrm{NO}_{2}^{-}\right)$with the oxidation of 1 molecule of ammonium $\left(\mathrm{NH}_{4}{ }^{+}\right)$to produce $\mathrm{N}_{2}$ under anaerobic conditions (van de Graaf et al. 1995). Anammox, shown to occur in estuarine systems around the world, also exhibits spatial and temporal variations related to biological and geochemical parameters, such as temperature, (Rysgaard et al. 2004), salinity (Rich et al. 2008), organic carbon content (Trimmer et al. 2003) and substrate availability (Risgaard-Petersen \& Meyer 2004, Trimmer et al. 2005, Rich et al. 2008, Nicholls \& Trimmer 2009). Higher potential anammox rates and contribution to total $\mathrm{N}_{2}$ production (\%anammox) have been consistently observed in the oligohaline reaches of estuaries, relative to higher salinities (Trimmer et al. 2003, Meyer et al. 2005, Koop-Jakobsen \& Giblin 2009, Minjeaud et al. 2009).

Investigations of anammox bacterial communities in estuarine sediments revealed spatial variation in community structure in relation to an estuarine salinity gradient. 'Candidatus Scalindua spp.' dominated throughout the estuarine systems (Risgaard-Petersen \& Meyer 2004, Tal et al. 2005, Amano et al. 2007, Rich et al. 2008, Dang et al. 2010, Hirsch et al. 2011), while 'Candidatus Brocadia', 'Candidatus Kuenenia', 'Candidatus Anammoxoglobous' and 'Candidatus Jettenia' were primarily detected in fresh to oligohaline sediment communities (Zhang et al. 2007, Dale et al. 2009, Li et al. 2010, Amano et al. 2011, Hirsch et al. 2011).

It has been suggested that variability in anammox activities and contribution to local and regional $\mathrm{N}$ loss are probably due to abundance, composition and distribution of anammox bacteria (Dang et al. 2010), which are in turn constrained by environmental parameters, such as salinity and substrate availability. If this is the case, shifts in anammox community structure and activities should covary with environmental parameters. However, the majority of studies exploring anammox in estuaries reported either community structure based on 16S rRNA and hydrazine oxidoreductase gene (hzo) analyses (Tal et al. 2005, Amano et al. 2007, Rich et al. 2008, Dale et al. 2009, Dang et al. 2010, Hirsch et al. 2011) or rate measurements using ${ }^{15} \mathrm{~N}$ isotope incubation methods (Thamdrup \& Dalsgaard 2002, Trimmer et al. 2003, Risgaard-Petersen \& Meyer 2004, Meyer et al. 2005, Koop-Jakobsen \& Giblin 2009, Nicholls \& Trimmer 2009). Thus, the coupling between community structure and activity rates of anammox communities along with spatial and temporal gradients in estuarine ecosystems has not been directly addressed.

Furthermore, geomorphological characteristics and water residence time of a system influence nutrient cycling and availability for biological use (Ensign \& Doyle 2006), as well as community composition (Crump et al. 2004). Systems governed by periodic anoxic events lead to spatial separation of the coupled aerobic nitrification and anaerobic denitrification processes, resulting in a strong temporal link between the 2 processes (Seitzinger et al. 2006). In these systems, $\mathrm{NO}_{3}{ }^{-}$is supplied primarily through advection of high-nutrient waters and denitrification occurs continuously. Findings by Kana et al. (1998) suggest that sediment denitrifying microbial populations remain poised to use $\mathrm{NO}_{3}{ }^{-}$and short-term temporal changes in $\mathrm{NO}_{3}{ }^{-}$concentrations in the overlying water control denitrification rates in these communities.

The degree of meteorological forcing, such as freshwater flushing, has also been shown to govern biological activities in estuarine systems (Peierls et al. 2012, Anderson et al. 2013, Hall et al. 2013). During moderate hydrologic forcing and high new nutrient loads, a system tends towards higher productivity and increased biomass. Excessively higher hydrologic forcing can overshadow nutrient availability however by increasing freshwater discharge and thereby reducing residence time, primary productivity and biomass, exerting a top-down control on community structure. As a result, it is important to consider different estuarine systems and the potential effects that meteorological forcing may have on microbial community structure and activities. This is especially true for slow-growing organisms, such as anammox bacteria, which may adapt differently to environments that experience periods of stagnation followed by pulses of high-nutrient freshwater. 
Studies conducted on anammox activities and community structure in estuarine systems have captured the dynamics of anammox in various estuarine settings (Meyer et al. 2005, Rich et al. 2008, Nicholls \& Trimmer 2009), mangrove sediments (Meyer et al. 2005), coastal marine sediments (Rysgaard et al. 2004, Dalsgaard et al. 2005, Engström et al. 2005) and anoxic marine systems (Jensen et al. 2008). Episodic inflow events have been shown to cause a switch from denitrification to anammox as the main form of nitrogen loss in the Baltic Sea (Hannig et al. 2007); however, limited studies have been conducted in shallow estuarine systems that experience these dramatic shifts in environmental conditions.

The goal of this study was to investigate linkages between the structure and activity of anammox communities corresponding to spatial variations of environmental conditions and episodic flushing events in the New River Estuary, North Carolina, USA. A 4-fold approach was used to define these linkages: (1) full characterization of environmental parameters previously associated with anammox rates and community structure were conducted; (2) ${ }^{15} \mathrm{~N}$ tracer incubation experiments with sediment slurries were used to measure the potential rates of anammox and denitrification with respect to environmental conditions; (3) molecular analyses of hzo genes were conducted to examine composition and abundance of anammox communities in sediments; and (4) multi-regression and multidimensional statistical methods were employed to assess the nature and extent of covariance among anammox community structure, activities of anammox communities (in absolute terms and relative to denitrification) and environmental parameters in the New River Estuary.

\section{MATERIALS AND METHODS}

\section{Site description}

The New River Estuary (NRE), Onslow Bay, North Carolina, USA, is a coastal plain estuary consisting of a series of shallow ( $<5 \mathrm{~m}$ deep), broad lagoons connected by narrow channels. High concentrations of humic materials and tannic acids (Dame et al. 2000, Dafner et al. 2007) characterize the upper estuary and the lower estuary is bordered by intertidal wetlands. The NRE watershed encompasses a $1436 \mathrm{~km}^{2}$ area draining mostly forest and agricultural lands in the upper regions of the watershed (Burkholder et al. 1997, Mallin et al. 2005). Within the watershed are over 138 registered swine facilities with 150000 ani- mals and poultry farms containing over 1 million birds. The City of Jacksonville located in Wilson Bay and the United States Marine Corps Base at Camp Lejeune are also within the watershed. Barrier islands at the mouth of the NRE restrict tidal exchange and are likely responsible for the relatively long (64 d) mean flushing time in this estuary (Ensign et al. 2004). The North Carolina Division of Environmental Management has classified the NRE as 'nutrient sensitive' since 1998, with nitrogen being the limiting nutrient of pelagic and benthic productivity in this eutrophic coastal system (Mallin et al. 2000). Shifts in seasonal wet and dry periods and episodic storm activity further impact nutrient loads and water residence times, leading to pulsed events that alter biological structure and function of this estuary as a benthic filter (Peierls et al. 2012, Anderson et al. 2013, Hall et al. 2013).

\section{Seasonal sampling}

Sampling was conducted seasonally (summer, fall, winter, spring) during 2009 to 2010 along nutrient and salinity gradients from the headwaters to the mouth of the estuary to capture intermittent flushing events. Summer (June 2009) and fall (September 2009) sampling events were conducted under normal conditions with rates of $<1$ and $<5 \mathrm{~m}^{3} \mathrm{~s}^{-1}$ freshwater discharge, respectively (Peierls et al. 2012). Winter sampling (December 2009) followed several pulsed discharge events ranging from $<5$ to $>25 \mathrm{~m}^{3} \mathrm{~s}^{-1}$ freshwater discharge, leading to elevated levels of new nutrients, likely from land-based sources, that remained in the system for several months. Spring sampling (April 2010) occurred at the tail end of these winter and spring episodic events during what was considered a relatively wet year, when freshwater discharge declined to $<1 \mathrm{~m}^{3} \mathrm{~s}^{-1}$.

Seven sites were examined and included upper estuary sites AA2 $\left(34.76^{\circ} \mathrm{N}, 77.45^{\circ} \mathrm{W}\right)$, Jax $\left(34.73^{\circ} \mathrm{N}\right.$, $\left.77.43^{\circ} \mathrm{W}\right), \mathrm{M} 53\left(34.72^{\circ} \mathrm{N}, 77.43^{\circ} \mathrm{W}\right)$, mid-estuary sites M47 $\left(34.68^{\circ} \mathrm{N}, 77.39^{\circ} \mathrm{W}\right), \mathrm{M} 39\left(34.64^{\circ} \mathrm{N}, 77.36^{\circ} \mathrm{W}\right)$, and lower estuary sites M31 $\left(34.59^{\circ} \mathrm{N}, 77.40^{\circ} \mathrm{W}\right)$, M15 (34.55 $\left.\mathrm{N}, 77.35^{\circ} \mathrm{W}\right)$ (Fig. 1). All samples and measurements were collected in the channel west of the indicated channel markers.

\section{Environmental parameter measurements}

Environmental parameters, including water column depth, temperature, salinity and dissolved oxygen (DO), were measured in surface and bottom 


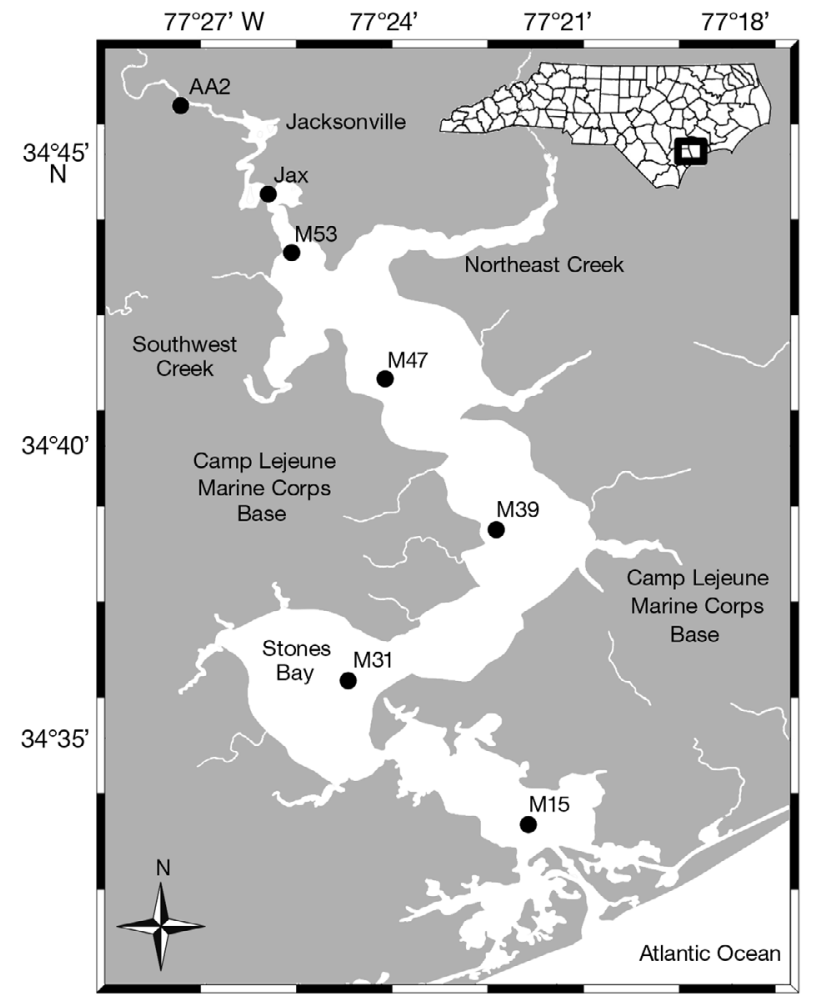

Fig. 1. Sampling sites in the New River Estuary, North Carolina, USA. Seven sites were examined and included upper (AA2, Jax and M53), mid- (M47 and M39) and lower (M31 and M15) estuary sites

waters (when site was $>1 \mathrm{~m}$ depth) at the time of sampling using a 6820 multi parameter YSI datasonde (YSI). Surface and bottom waters were $0.7 \mu \mathrm{m}$ filtered and stored on ice prior to nutrient analysis. Ammonium and $\mathrm{NO}_{3}{ }^{-}$concentrations were measured spectrophotometrically on a Bran Luebbe segmented flow nutrient autoanalyzer using phenol hypochlorite, and Cd-reduction and azo dye methods, respectively, following modified standard Environmental Protection Agency methods (Long \& Martin 1997).

Sediment samples were collected using a petite ponar grab (Wildco). The top $2 \mathrm{~cm}$ of sediment were collected and used to pack full $50 \mathrm{ml}$ centrifuge tubes (BD Biosciences) and stored on ice. In the laboratory, porewater was extracted by centrifugation and analyzed for ferrous iron $\left(\mathrm{Fe}^{2+}\right.$; Stookey 1970) and hydrogen sulfide $\left(\mathrm{H}_{2} \mathrm{~S}\right.$; Cline 1969). Porewater $\mathrm{NO}_{3}{ }^{-}+\mathrm{NO}_{2}{ }^{-}$ $\left(\mathrm{NO}_{\mathrm{x}}{ }^{-}\right)$was measured using vanadium (III) reduction and chemiluminescent detection (Braman \& Hendrix 1989). Sediment percent organic content was determined by loss on ignition of dried sediments $\left(500^{\circ} \mathrm{C}\right.$ for $4 \mathrm{~h}$ ). Sediment $\mathrm{NH}_{4}{ }^{+}$(free plus extractable) was measured by phenol hypochlorite following $\mathrm{KCl}$ extraction using a 1:1 ratio of $\mathrm{KCl}$ to sediments (Mackin \& Aller 1984). Benthic chlorophyll $a$ analysis on $2 \mathrm{~cm}$ thick sediment plugs was conducted as described by Whitney \& Darley (1979). Mean sediment grain size was determined after organic material was dissolved with $35 \% \mathrm{H}_{2} \mathrm{O}_{2}$ using a LS 200 Beckman Coulter Particle Sizer (Bechman Coulter). Sediments from each site were stored at $-80^{\circ} \mathrm{C}$ for molecular analysis.

\section{${ }^{15} \mathrm{~N}$ tracer incubations}

Sediment slurry incubation experiments with ${ }^{15} \mathrm{~N}$ tracer were conducted to measure potential rates of denitrification and anammox using a modified method of Dale et al. (2009). Eight sediment slurries containing $2 \mathrm{~g}$ of homogenized sediment and porewater were pre-incubated in helium-purged Exetainer tubes (Labco) in the dark overnight to remove residual $\mathrm{NO}_{\mathrm{x}}{ }^{-}$. After pre-incubation, 2 of the Exetainers were sacrificed to measure residual $\mathrm{NO}_{\mathrm{x}}{ }^{-}$in sediment porewater (Braman \& Hendrix 1989). The residual concentration of $\mathrm{NO}_{\mathrm{x}}^{-}$was used to correct the mole fraction ${ }^{15} \mathrm{~N}$ enrichment of the added ${ }^{15} \mathrm{NO}_{3}{ }^{-}$(Song \& Tobias 2011) in subsequent rate calculations for anammox and denitrification. Remaining Exetainer tubes with sediment slurries were again purged with helium, amended with 200 nmoles ${ }^{15} \mathrm{NO}_{3}{ }^{-}$and 200 nmoles ${ }^{14} \mathrm{NH}_{4}{ }^{+}$and placed in the dark during incubations. Time series incubations were carried out in duplicates and the activities stopped by the addition of saturated $\mathrm{ZnCl}_{2}$. Production of ${ }^{29} \mathrm{~N}_{2}$ and ${ }^{30} \mathrm{~N}_{2}$ was measured on an Isotopic Ratio Mass Spectrometer (Delta V Plus, Thermo Fisher Scientific) and used to calculate the rate of anammox and denitrification following the method of Thamdrup \& Dalsgaard (2002) as modified by Song \& Tobias (2011). Percent anammox (\%anammox) was estimated based on the rates of anammox and total $\mathrm{N}_{2}$ production in each sample.

\section{DNA extraction}

Sediment DNA was extracted using PowerSoil DNA Kit (Mo-Bio Laboratories) following the manufacturer's protocol with 2 modifications: (1) the amount of wet sediment was increased to $0.6 \mathrm{~g}$ and (2) a Thermo Savant Fast Prep FP 120 Cell Disrupter (Qbiogene) was used for cell disruption.

\section{Quantitative PCR amplification of hzo genes}

Quantitative PCR (qPCR) of hzo genes was carried out to measure the abundance of anammox bacteria 
in the NRE sediments following the method of Long et al. (2013). The PCR mixture contained the HZAOQPCR1F and HZOQPCR1R primers, sediment DNA (3 $\mathrm{ng} \mathrm{hl}^{-1}$ ) and the Go-Taq qPCR Master Mix (Promega). PCR specificity was monitored by analysis of dissociation curves. The $\mathrm{R}^{2}$ values for the standard curves were $>0.996$ and the detection limit of hzo qPCR was 78 hzo gene copies per sample.

\section{PCR amplification, cloning of PCR products and sequencing}

To examine the composition of anammox communities exposed to different freshwater discharge rates, nested PCR of the hzo genes was conducted with winter and summer samples using the Go-Taq Master Mix (Promega) under the following PCR conditions: $95^{\circ} \mathrm{C}$ for $5 \mathrm{~min}, 94^{\circ} \mathrm{C}$ for $1 \mathrm{~min}, 55^{\circ} \mathrm{C}$ for $1 \mathrm{~min}$, $72^{\circ} \mathrm{C}$ for $1 \mathrm{~min}, 35$ times, $95^{\circ} \mathrm{C}$ for $1 \mathrm{~min}, 55^{\circ} \mathrm{C}$ for $1 \mathrm{~min}, 72^{\circ} \mathrm{C}$ for $10 \mathrm{~min}$. The initial PCR reaction was conducted with the primers HZO4F and HZO1R (Hirsch et al. 2011) to amplify a 1037 bp region of the hzo gene. A second nested reaction was conducted using the initial PCR reaction mixture as a template and the primers hzocl1 F1 and hzocl1 R2 (Schmid et al. 2008) to generate $470 \mathrm{bp}$ fragments.

The nested PCR products were purified using UltraClean GelSpin DNA Purification Kit (Mo-Bio) and cloned using Perfect Prep Cloning Kit (5 Prime). At least 24 clones were picked for hzo gene library constructions. Sequencing was conducted with the Big Dye Terminator version 1.1 and a 3130x Genetic Analyzer sequencing machine (Applied Biosystems).

\section{Phylogenetic analysis of hzo genes}

The hzo gene sequences were assembled and edited using the SeqMan program (DNASTAR Lasergene) and compared with hzo gene sequences available in the GenBank database (www.ncbi.nlm.nih. gov). The hzo gene sequences were translated to amino acid sequences using Transeq (European Bioinformatics Institute www.ebi.ac.uk/Tools/st/ emboss_transeq/). Translated hzo sequences were aligned with reference sequences using Mega 5.1. A phylogenetic tree was constructed using the neighbor-joining method with the Poisson model. Representative hzo sequences were selected within the sequences sharing $100 \%$ identity. The number of sequences is denoted in parentheses of a representative sequence in the phylogenetic tree. Bootstrap analysis of 1000 repetitions was used to test the confidence of phylogenetic reconstruction with $50 \%$ support threshold. Hzo protein similarity was determined using pairwise distance computation in MEGA 5.1. The hzo gene sequences are available at GenBank with the accession numbers KF192638 to KF192691.

\section{Statistical analysis}

Several statistical evaluations of the data were conducted. First, 2-way ANOVA was conducted to identify significant differences among anammox activities by location within the estuary and season using $\mathrm{R}$ (version 2.15.3, R Foundation for Statistical Computing). Correlation analyses were also conducted to identify relationships between anammox rates, anammox gene abundance and community structure, and environmental parameters, also using $\mathrm{R}$ (version 2.15.3, R Foundation for Statistical Computing). A weighted principal components analysis (PCA) using UniFrac (http://bmf2.colorado.edu/unifrac/index.psp) was conducted to examine anammox community structure based on sequence dissimilarities between sites in the estuary (Lozupone \& Knight 2005). UniFrac was also used to determine significant differences in community structure using cluster analysis that was corrected for the number of pairwise comparisons using the Bonferroni correction. Non-metric multidimensional scaling (NMDS) was then performed to explore relationships between anammox community structure and environmental parameters in the NRE using the function meta-MDS in the vegan package in $\mathrm{R}$ (version 2.15.3, R Foundation for Statistical Computing).

\section{RESULTS}

\section{Environmental characteristics}

Bottom water temperature was generally uniform throughout the estuary during each season ranging from $13.5 \pm 2.5( \pm \mathrm{SE}){ }^{\circ} \mathrm{C}$ in the winter to $27.7 \pm 0.6^{\circ} \mathrm{C}$ in summer (Table 1). Salinity in the upper and mid reaches of the estuary varied by a factor of 10 depending on river discharge (Table 1). The highest salinities were encountered in fall and spring. Winter sampling was coincident with large freshwater inputs from the watershed that completely freshened the uppermost station AA2. Elevated levels of bottom water $\mathrm{NO}_{3}{ }^{-}$and $\mathrm{NH}_{4}{ }^{+}$were observed throughout the 
Table 1. Seasonal environmental parameters of New River Estuary bottom water; nd: not determined

\begin{tabular}{|c|c|c|c|c|c|c|c|c|c|c|c|c|c|c|c|c|c|c|c|c|}
\hline \multirow[t]{2}{*}{ Site } & \multicolumn{4}{|c|}{ Temperature $\left({ }^{\circ} \mathrm{C}\right)$} & \multicolumn{4}{|c|}{ Salinity } & \multicolumn{4}{|c|}{ Nitrate $(\mu \mathrm{M})$} & \multicolumn{4}{|c|}{ Ammonium $(\mu \mathrm{M})$} & \multicolumn{4}{|c|}{$\begin{array}{c}\text { Dissolved oxygen } \\
\left(\mathrm{mg} \mathrm{l}^{-1}\right)\end{array}$} \\
\hline & Jun & Sep & Dec & Apr & Jun & Sep & Dec & Apr & Jun & Sep & Dec & Apr & Jun & Sep & Dec & Apr & Jun & Sep & Dec & Apr \\
\hline AA2 & 28.8 & 24.0 & nd & 21.2 & 2.2 & 9.3 & 0.1 & 9.1 & .40 & nd & 68.61 & 0.44 & 9.05 & nd & 2.54 & 7.80 & 0.2 & 0.9 & 6.4 & 0.6 \\
\hline Jax & 27.7 & 25.1 & nd & 21.2 & 12.3 & 13.6 & 5.7 & 17.8 & 0.64 & nd & 13.30 & 0.25 & 2.75 & nd & 14.89 & 0.75 & 3.0 & 2.2 & 7.0 & 4.1 \\
\hline M53 & 26.9 & 24.5 & nd & 21.1 & 13.2 & 14.1 & 6.6 & 18.6 & nd & nd & 9.00 & 0.19 & nd & nd & 14.66 & 1.01 & 4.0 & 4.7 & 7.0 & 3.4 \\
\hline M47 & 27.3 & 22.7 & 11.8 & 19.9 & 18.8 & 13.3 & 5.2 & 16.4 & 0.70 & nd & 13.78 & 0.37 & 1.27 & nd & 14.76 & 1.18 & 4.4 & 7.5 & 10.2 & 7.9 \\
\hline M39 & 27.2 & 23.4 & 11.7 & 20.0 & 20.8 & 16.6 & 10.2 & 22.0 & 1.05 & nd & 9.26 & 0.33 & 1.92 & nd & 9.28 & 0.92 & 3.0 & 7.0 & 9.5 & 7.9 \\
\hline M31 & 27.8 & 23.8 & nd & 19.2 & 23.3 & 20.5 & 12.3 & 27.0 & 0.17 & nd & 6.44 & 0.47 & 0.51 & nd & 9.41 & 1.45 & nd & 6.2 & 7.4 & 7.6 \\
\hline M15 & 28.1 & 23.1 & 17.0 & 17.8 & 31.0 & 29.3 & 29.8 & 33.6 & 0.65 & nd & 0.72 & 0.62 & 5.43 & nd & 1.12 & 1.32 & nd & 7.1 & 6.5 & 8.2 \\
\hline
\end{tabular}

estuary during winter sampling, coincident with the winter freshening event (Table 1). The highest bottom water $\mathrm{NO}_{3}{ }^{-}$and $\mathrm{NH}_{4}{ }^{+}$concentrations were at upper and mid-estuary winter sites, reaching 68.61 and $14.89 \mu \mathrm{M}$, respectively. Bottom water hypoxia, where DO levels were $<5 \mathrm{mg} \mathrm{l}^{-1}$, was observed throughout the estuary during summer and at upper estuary stations during fall and spring (Table 1).

Iron $\left(\mathrm{Fe}^{2+}\right)$ concentration in porewater varied between sites and seasons with the highest observed concentration of $\mathrm{Fe}^{2+}$ exceeding $70 \mu \mathrm{M}$ at the lower estuary M31 station during the winter (Table 2).
Hydrogen sulfide $\left(\mathrm{H}_{2} \mathrm{~S}\right)$ concentrations ranged from 0.2 to $1100 \mu \mathrm{M}$, with elevated concentrations consistently in the upper and mid-estuary (Table 2). Porewater $\mathrm{NO}_{\mathrm{x}}{ }^{-}$was greater throughout the estuary during the spring; however, the highest overall concentration was observed in winter at the Jax station (Table 2).

Sediment \%organics were highest at the upper and mid-estuary sites during all seasons sampled. High organic content was coincident with the highest porewater $\mathrm{H}_{2} \mathrm{~S}$ concentrations at these sites (Table 3). Extractable sediment $\mathrm{NH}_{4}{ }^{+}$concentrations were below $0.5 \mu \mathrm{mol} \mathrm{NH}_{4}{ }^{+} \mathrm{g}^{-1}$ wet sediment in summer and spring, while $\mathrm{NH}_{4}{ }^{+}$concentrations in the winter exceeded $1 \mu \mathrm{mol} \mathrm{NH}_{4}{ }^{+} \mathrm{g}^{-1}$ wet sediment at 4 sites (Table 3). Benthic chlorophyll a was highest in winter at mid-estuary sites, with values ranging from 13 to $24 \mu \mathrm{g}$ chlorophyll a $\mathrm{g}^{-1}$ sediment (Table 3 ). Sediment grain size increased from fine sand and silt in the upper estuary to fine-medium grained sands towards the mouth of the estuary (Table 3).

Table 3. New River Estuary sediment (sed.) characteristics; nd: not determined

\begin{tabular}{|c|c|c|c|c|c|c|c|c|c|c|c|c|c|c|c|c|}
\hline \multirow[t]{2}{*}{ Site } & \multicolumn{4}{|c|}{ Sediment organics (\%) } & \multicolumn{4}{|c|}{$\begin{array}{c}\text { Ammonium } \\
\left(\mu \mathrm{mol} \mathrm{g}{ }^{-1} \text { wet sed.) }\right.\end{array}$} & \multicolumn{4}{|c|}{$\begin{array}{l}\text { Benthic chl a } \mu g \text { chl } a \\
\qquad(\mathrm{~g} \text { sed. })^{-1}\end{array}$} & \multicolumn{4}{|c|}{ Sediment grain size $(\mu \mathrm{m})$} \\
\hline & Jun & Sep & Dec & Apr & Jun & Sep & Dec & Apr & Jun & Sep & Dec & Apr & Jun & Sep & Dec & Apr \\
\hline AA2 & 3.21 & nd & 2.96 & 15.57 & 0.14 & nd & 0.20 & 0.06 & 0.00 & 1.83 & 0.00 & 7.75 & 35.8 & 121.9 & 344.1 & 23.5 \\
\hline Jax & 14.71 & nd & 22.96 & 17.98 & 0.36 & nd & 1.24 & 0.21 & 5.98 & 3.54 & 4.68 & 4.34 & 35.7 & 75.7 & 54.7 & 105.7 \\
\hline M53 & 17.17 & nd & 18.46 & 20.69 & 0.42 & nd & 1.22 & 0.33 & 5.17 & 0.00 & 14.54 & 0.00 & 24.2 & 37.7 & 30.3 & 17.9 \\
\hline M47 & 14.66 & nd & 17.62 & 18.95 & 0.50 & nd & 1.04 & 0.28 & 4.60 & 3.38 & 13.48 & 5.43 & 19.4 & 30.8 & 58.6 & 38.2 \\
\hline M39 & 11.66 & nd & 11.46 & 12.29 & 0.45 & nd & 0.47 & 0.24 & 4.25 & 0.00 & 25.41 & 8.32 & 29.1 & 34.8 & 30.6 & 35.8 \\
\hline M31 & 9.21 & nd & 9.51 & 10.19 & 0.19 & nd & 1.21 & 0.20 & 4.92 & 6.46 & 17.35 & 8.97 & 28.3 & 41.9 & 33.9 & 36.0 \\
\hline M15 & 0.34 & nd & 0.13 & 0.33 & 0.12 & nd & 0.13 & 0.04 & 4.03 & 4.98 & 7.84 & 5.36 & 181.8 & 244.8 & 251.4 & 291.0 \\
\hline
\end{tabular}


In summary, the low salinity upper estuary sites (AA2, Jax and M53) were generally lower in DO and higher in $\mathrm{NO}_{3}{ }^{-}$and $\mathrm{NH}_{4}{ }^{+}$than the middle and lower sites. These sites contained medium silt to fine sand sediments that were moderately rich in organic content and variable in ferrous iron and sulfide. Mid-estuary sites (M47 and M39) were representative of a transitional salinity and DO gradient, while elevated in $\mathrm{H}_{2} \mathrm{~S}, \mathrm{NH}_{4}{ }^{+}$and $\mathrm{NO}_{3}{ }^{-}$concentrations. Lower estuary sites (M31 and M15) were highest in salinity and DO, and lower in $\mathrm{NO}_{3}{ }^{-}$concentrations. They contained medium silt to sandy sediments with higher ferrous iron and chlorophyll a content. Overall, spatial variations in salinity and dissolved oxygen were observed consistently throughout the estuary. Temporal variance among sites occurred, but did not show a smooth seasonal cyclic pattern at any given site. Instead, seasonal trends were superseded by pulses of nutrients that were observed and elevated throughout a major portion of the estuary. The occurrence of these pulses were evident in bottom water $\mathrm{NO}_{3}{ }^{-}$and $\mathrm{NH}_{4}{ }^{+}, \mathrm{H}_{2} \mathrm{~S}$ porewater and sediment $\mathrm{NH}_{4}{ }^{+}$concentrations, where trends of elevated levels were observed throughout large portions of the estuary following periods of high freshwater discharge events.

\section{Anammox and denitrification activities and their correlation to environmental parameters}

Production of ${ }^{30} \mathrm{~N}_{2}$ (denitrification) and ${ }^{29} \mathrm{~N}_{2}$ (anammox) was immediately observed in the sediment incubations and the 2 processes were positively and significantly correlated with each other $(\mathrm{p}=0.013, \mathrm{r}=$ 0.624). Both $\mathrm{N}_{2}$-producing processes were detected at all sites throughout the estuary during all 4 seasons. Potential denitrification rates ranged from 0.4 to $31 \mathrm{nmol} \mathrm{N} \mathrm{g}^{-1} \mathrm{~h}^{-1}$, while anammox rates were lower at 0.02 to $1.4 \mathrm{nmol} \mathrm{N}_{2} \mathrm{~g}^{-1} \mathrm{~h}^{-1}$ (Table A1 in Appendix 1). The overall average of \%anammox for the NRE was $5.2 \%$ and ranged from 1.8 to $14.1 \%$; the highest contribution of anammox occurred in the AA2 sediment community during spring (Table A1).

For all seasons, the distribution of denitrification and anammox rates as well as \%anammox along the estuary was variable. There was, however, a spatial trend of higher activities in the upper estuary relative to lower activities towards the mouth of the estuary ( $p=0236, p=0.0018$ and $p=0.031$ for denitrification, anammox and \%anammox, respectively; Fig. 2). Seasonal fluctuations in anammox and denitrification rates were also observed in the NRE with significant differences observed during spring relative to the other seasons $(\mathrm{p}=0.021, \mathrm{p}=0.00453$ and $\mathrm{p}=0.0153$ for denitrification, anammox and \%anammox, respectively).

Potential denitrification rates were positively correlated with $\mathrm{H}_{2} \mathrm{~S}(\mathrm{p}=0.002, \mathrm{r}=0.5139)$, \%organics $(p=0.009, r=0.5936)$ and extractable sediment $\mathrm{NH}_{4}{ }^{+}$ $(\mathrm{p}=0.002, r=0.2635)$. Anammox rates also significantly correlated with increasing levels of porewater $\mathrm{H}_{2} \mathrm{~S}(\mathrm{p}=0.009, \mathrm{r}=0.5681)$ and sediment \%organics ( $p=0.005, r=0.6829)$, but were negatively correlated with salinity $(p=0.004, r=-0.3956)$, while \%anammox showed a negative correlation with DO levels $(p=0.004, r=-0.5364)$. This is the first reporting of a significant positive correlation between anammox activity and porewater sulfide in sediments.

\section{Anammox bacterial abundance and its correlation to environmental parameters}

Based on hzo gene qPCR, spatial and temporal abundance of anammox bacteria were compared in the sediment samples collected in summer and winter. Abundance of hzo genes ranged from $1.55 \times 10^{2}$ to $2.59 \times 10^{5}$ copies $g^{-1}$ sediment (Fig. 3, Table A2). These values fell within the lower ranges of previously published values for hzo gene abundance in the environment (Dang et al. 2010, Hong et al. 2011). The lowest anammox bacterial abundance was found in the summer at M15, corresponding to relatively lower activities. Seasonal variation in anammox abundance was observed, with the highest values observed during summer at AA2, Jax, M47 and M39, and during winter at M53, M31 and M15.

Anammox bacterial abundance was significantly and positively correlated with anammox activities $(\mathrm{p}=0.033, \mathrm{r}=0.4336)$, porewater $\mathrm{H}_{2} \mathrm{~S}$ concentrations $(\mathrm{p}=0.0456, \mathrm{r}=0.5412)$ and sediment \%organics $(\mathrm{p}=$ $0.033, r=0.5715)$. Independent positive relationships between the covarying estuarine conditions (porewater $\mathrm{H}_{2} \mathrm{~S}$ and sediment \% organics) with hzo gene abundance and potential anammox $\mathrm{N}_{2}$ production in the NRE may demonstrate that environmental conditions influence anammox abundance, which in turn influences potential anammox activities. This association was explored further in anammox community composition based on sequence analysis of hzo genes.

\section{Spatial and temporal variation of anammox community composition}

Nested PCR amplified $470 \mathrm{bp}$ fragments of hzo genes in the summer and winter samples. Eighty- 

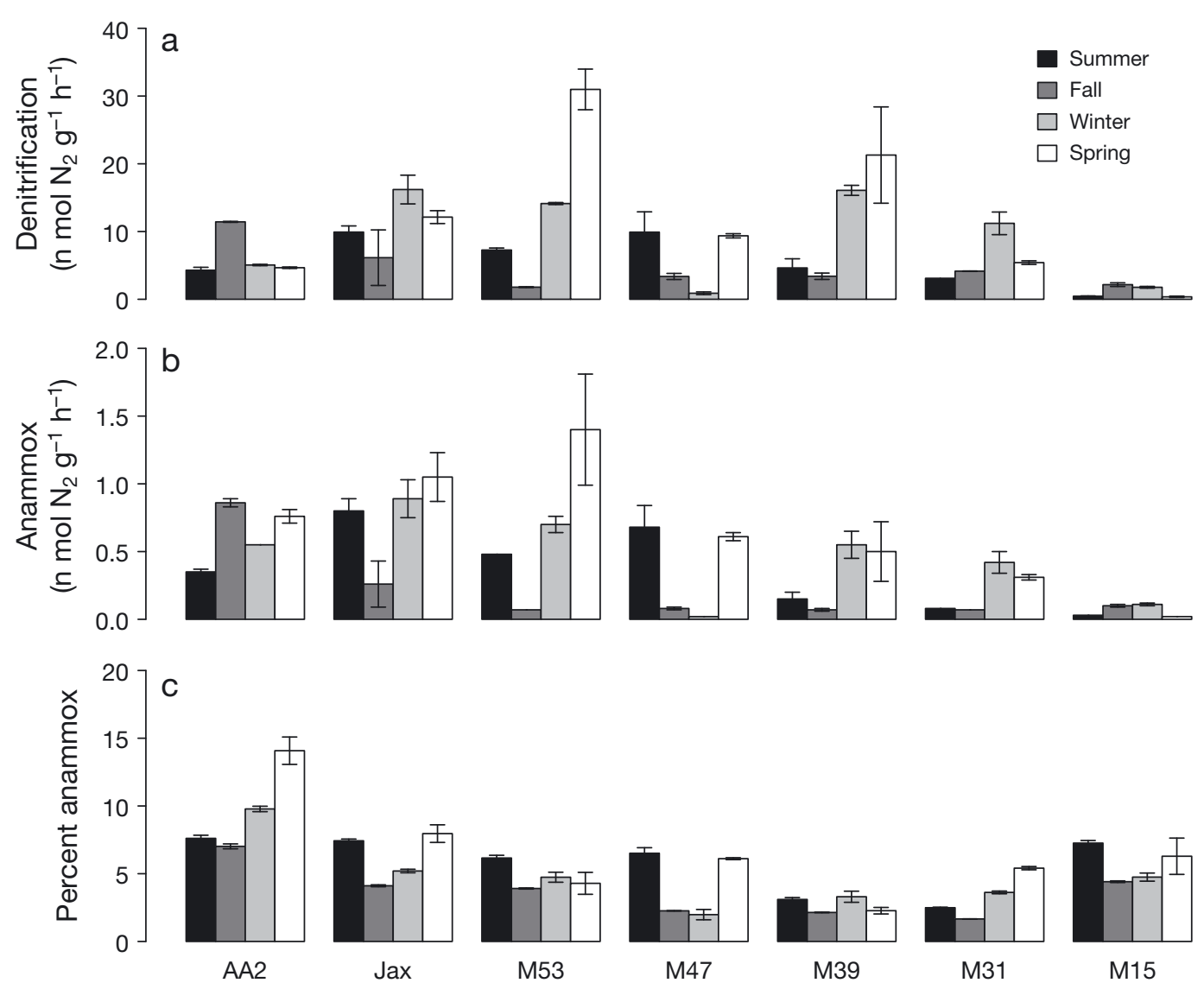

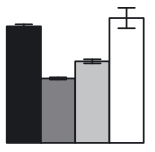

Jax

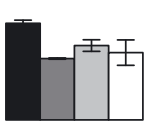

M53

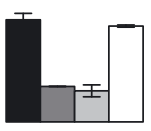

M47

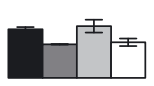

M39

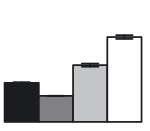

M31

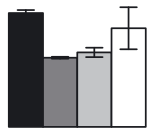

M15

Fig. 2. Seasonal comparison of rates of denitrification and anammox, and percent anammox in the New River Estuary. Potential $\mathrm{N}_{2}$ production of (a) denitrification, (b) anammox, and (c) \%anammox. Samples were oriented from headwaters to mouth of the estuary on the $x$ axis. Error bars represent standard error

seven sequences of the hzo genes were obtained and translated to amino acid sequences prior to phylogenetic analysis. All hzo sequences showed high similarity (>69.7\% amino acid similarity) to the translated hzo genes in hzo cluster 1 (Schmid et al. 2008). In general, hzo sequences found throughout the NRE formed 2 clusters, designated 'Jettenia' and 'Scalindua' clusters, dominated by 'Jettenia-like' anammox.

A discernible spatial pattern of anammox sequences was not observed in the NRE. Most sequences detected in the upper and mid-estuary sites, as well as the M15 winter sample, were assigned to the Jettenia cluster as they showed $>88.9 \%$ hzo amino acid sequence similarity with the 'Candidatus Jettenia' enrichment culture clone ANAHZO3 (Fig. 4). A combined group of sequences from the upper and midestuary site samples collected in summer and winter, as well as lower estuary (M15) winter sequences, closely associated with the hzo sequences detected in North Carolina aquifers, freshwater sites of Cape Fear River Estuary (Hirsch et al. 2011) and the ANAHZO3 sequence from an activated sludge reac- tor (Quan et al. 2008). One sequence related to the hzo sequence of a Kuenenia enrichment culture was found in the M53 summer sample. Hzo sequences from M31 winter and M15 summer samples formed the Scalindua cluster, with $>88.5 \%$ similarity to the hzo sequence of 'Candidatus Scalindua sp.', Mai Po Mangrove (Li et al. 2010), South China Sea (Hong et al. 2011) and Jiaozhou Bay (Dang et al. 2010).

A sharp change of anammox community composition was observed at the M15 site and corresponded to changes in environmental conditions in the NRE. The M15 sediment sequences clustered with the Scalindua hzo sequences during the summer when the estuary was experiencing low-flow conditions. During the winter sampling, a higher diversity of phylotypes was seen at this site, all closely related to 'Candidatus Jettenia spp'. During the winter, the estuary experienced high freshwater inputs that led to elevated concentrations of $\mathrm{NO}_{3}{ }^{-}$throughout the estuary (Table 2). These nutrient data in conjunction with the hzo sequences suggest that a winter flushing of the NRE brought anammox bacteria present at 


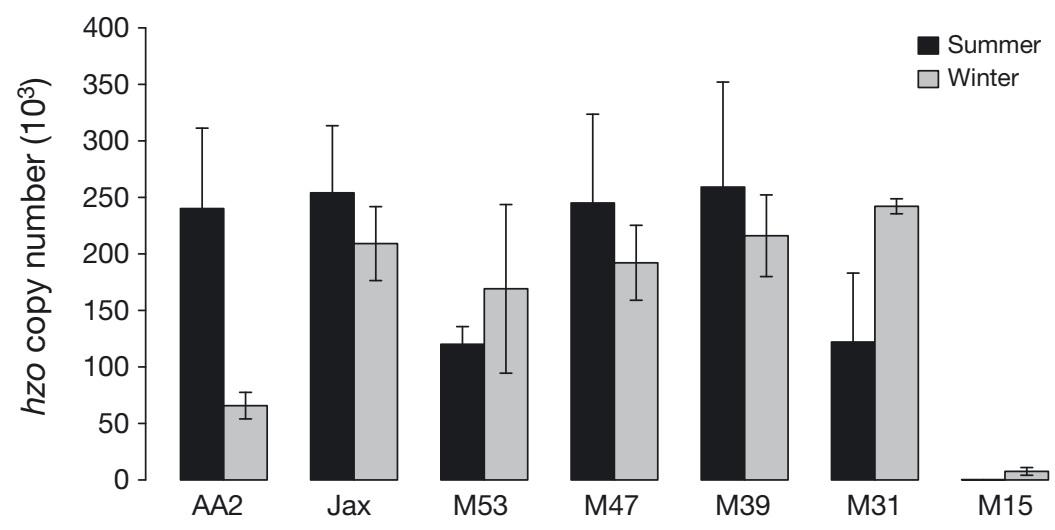

Fig. 3. Quantification of hzo genes in the New River Estuary sediment communities using quantitative PCR assays. Assays were conducted on summer and winter samples, indicated by black and dark gray bars, respectively. Error bars represent standard error

upper estuary sites throughout the estuary to the most saline site, during which potential activities increased, which suggests that the presence of Jettenia in these sediments led to greater nitrate removal. The hzo gene abundance and potential anammox activities at sites where 'Candidatus Jettenia spp.' dominated were positively correlated $(\mathrm{r}=0.635)$, although the observed relationship was not significant ( $p>0.05)$.

Overall, non-Scalindua organisms were shown to be the dominant anammox bacterial group in the NRE. The hzo sequences typically associated with Jettenia-like sequences found in fresh and oligohaline environments were widely distributed throughout the NRE. Additionally, anammox communities in the lower estuary site, M15, showed unique seasonal changes from Scalindua- to Jettenia-like organisms that have not yet been observed in other studies.

\section{Determination of environmental factors that influence anammox community composition}

Anammox hzo sequences were further analyzed to determine the environmental parameters influencing community composition. The UniFrac analysis enabled comparison of phylogenetic differences in anammox communities detected in the NRE through the application of PCA. PCA explained $90.83 \%$ of the variation observed in NRE anammox communities (data not shown). PC1 ( $x$ axis) explained $82.27 \%$ of the variation in communities, while PC2 ( $y$ axis) accounted for $8.56 \%$ of the variation in communities. Communities appeared to form 2 distinct clusters that were not significantly different from one another following Bonferroni correction $(p>0.05)$, likely due to the highly conserved hzo gene sequences between anammox groups. However, the PCA clearly demonstrated a difference among the sites that were dominated by Jetteniaand Scalindua-like organisms.

NMDS analysis was applied to the community structure matrix generated by UniFrac and compared with environmental parameters (Fig. 5). This enabled visualization of the influence of environmental parameters on the anammox communities in the NRE. The strongest relationship between the anammox community structure and environmental parameters was observed with salinity $\left(\mathrm{p}=0.054, \mathrm{R}^{2}=\right.$ $0.6274)$. Relationships between anammox community composition and environmental parameters were not deemed to be significant, likely due to a lower sample number for the sequence analysis in this study. However, weak relationships between salinity, porewater $\mathrm{H}_{2} \mathrm{~S}$ and sediment \%organics with anammox community composition are consistent with observations from anammox activity and abundance analyses.

\section{DISCUSSION}

Potential activities of denitrification and anammox and \%anammox observed in the NRE were dynamic but consistently higher at fresh to oligohaline sites and especially elevated during the spring. Rates and \%anammox observed in this study were on the same order of magnitude as those reported in other shallow coastal ecosystems that also describe upstream rate maxima (Thamdrup \& Dalsgaard 2002, Trimmer et al. 2003, Risgaard-Petersen \& Meyer 2004, Meyer et al. 2005, Rich et al. 2008, Dale et al. 2009, KoopJakobsen \& Giblin 2009, Nicholls \& Trimmer 2009). In these studies, spatial differences were attributed to availability of $\mathrm{NO}_{3}{ }^{-}$and $\mathrm{NO}_{2}{ }^{-}$in the suboxic zone of sediments with higher activity measurements in upper estuary sites (Trimmer et al. 2003, RisgaardPetersen \& Meyer 2004, Meyer et al. 2005, Rich et al. 2008, Koop-Jakobsen \& Giblin 2009, Nicholls \& Trimmer 2009). Anammox and denitrification in the NRE also showed temporal variability, with higher activities in spring, consistent with other aquatic studies (Risgaard-Petersen \& Meyer 2004, Hietanen \& Kuparinen 2007, Minjeaud et al. 2009).

In this study, the positive relationship of anammox activities and abundance with sediment \%organics and porewater $\mathrm{H}_{2} \mathrm{~S}$ demonstrates an interplay among 


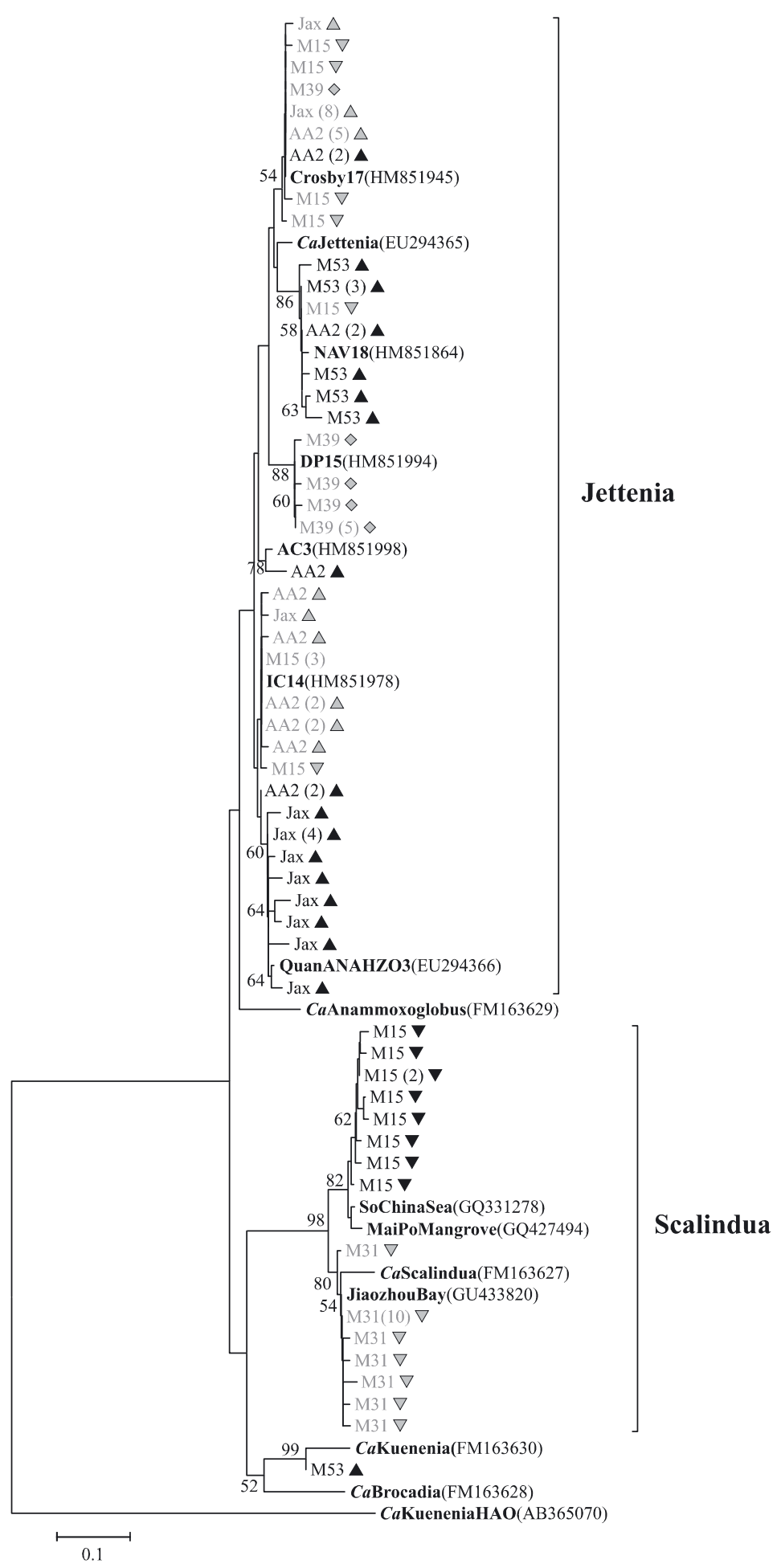

Fig. 4. Phylogenetic tree of translated hzo gene sequences depicting seasonal variation of anammox communities in New River Estuary sediments. Neighbor-joining trees were constructed and bootstrap analysis with 1000 replicates was used to estimate confidence. The outgroup sequence is the translated 'Candidatus $(\mathrm{Ca})$ Kuenenia sp.' hzo gene sequence. Bootstrap values of $>50 \%$ (from 1000 replicates). Clusters are marked by brackets and labeled according to the most closely related genus or genera. Sequences with $100 \%$ identity detected more than once are indicated by the number of times detected in parentheses. New River Estuary sites are labeled according to the site names and a symbol denoting location in the estuary; an upward-facing triangle indicates upper estuary sites (AA2, Jax and M53), a diamond is used for mid-estuary sites (M47 and M39) and a downward-facing triangle represents downstream sites (M31 and M15). Labels are also distinguished by season; summer (black) and winter (gray). Scale bar indicates 10\% sequence difference 


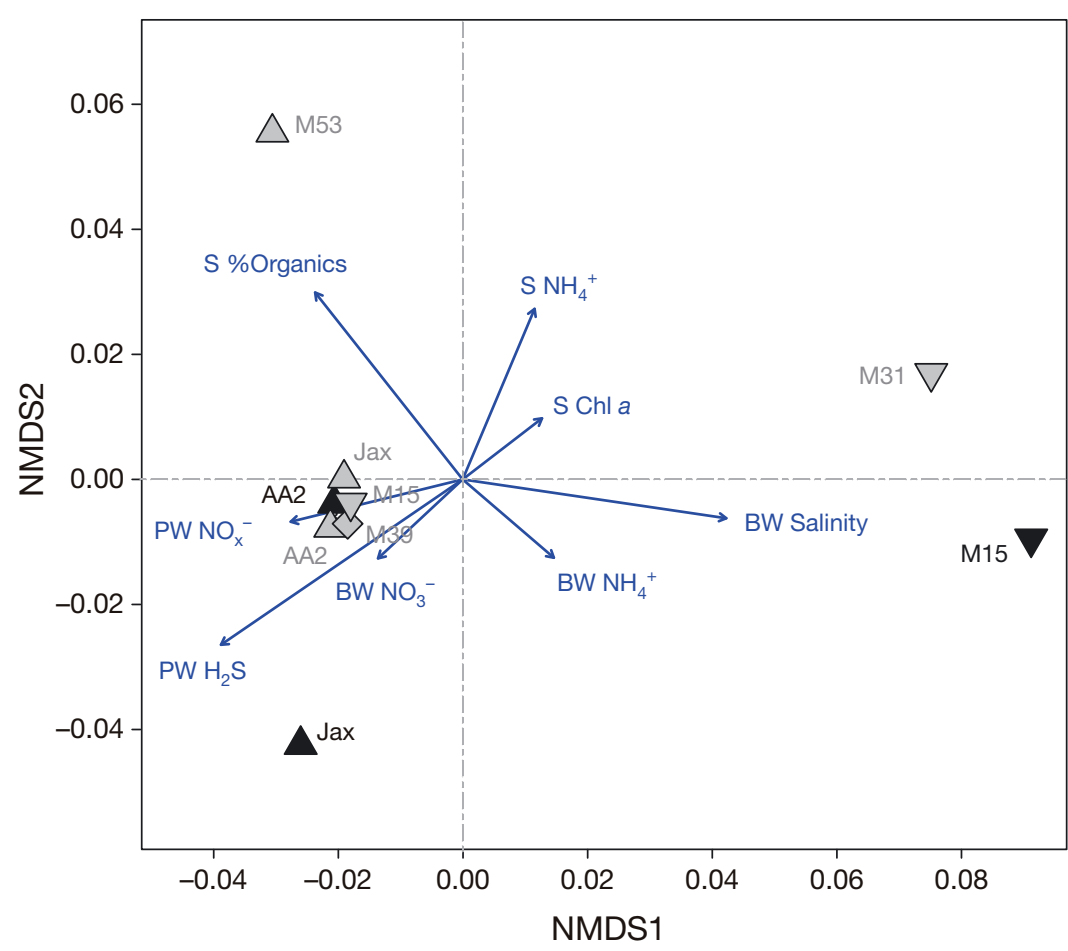

Fig. 5. Non-metric multidimensional scaling (NMDS) analysis comparing anammox community structure with environmental parameters. Anammox community structure was based on hzo sequence dissimilarities. Analyzed environmental parameters include (1) bottom water (BW) salinity, $\mathrm{NO}_{3}^{-}(\mu \mathrm{M})$ and $\mathrm{NH}_{4}{ }^{+}(\mu \mathrm{M}),(2)$ porewater (PW) $\mathrm{H}_{2} \mathrm{~S}(\mu \mathrm{M})$ and $\mathrm{NO}_{\mathrm{x}}{ }^{-}(\mu \mathrm{M})$, and (3) sediment (S) $\%$ organics, extractable sediment $\mathrm{NH}_{4}{ }^{+}\left(\mu \mathrm{mol} \mathrm{NH}{ }_{4}{ }^{+} \mathrm{g}^{-1}\right.$ wet sediment) and benthic chlorophyll a $\left(\mu \mathrm{g} \mathrm{chl} \mathrm{a} \mathrm{g} \mathrm{sed}^{-1}\right)$. See Fig. 4 for explanation of symbols

'Candidatus Anammoxoglobus propionicus', and 'Candidatus Brocadia fulgida' enrichment cultures (Strous et al. 2006, Kartal et al. 2008). This study provides further support that anammox bacteria may be capable of capitalizing on organic carbon, which may be of particular interest in the future when examining anammox bacteria in organic-rich estuarine systems.

An alternative explanation for the relationship between anammox and sediment \%organics includes the positive association with porewater $\mathrm{H}_{2} \mathrm{~S}$ and points to a coupling of the nitrogen and sulfur cycles in the NRE. Micromolar concentrations of $\mathrm{H}_{2} \mathrm{~S}$ were initially reported to inhibit activity of anammox (Jensen et al. 2008), possibly due to direct inhibition (Dalsgaard et al. 2003). However, a more recent study examining the influence of $\mathrm{H}_{2} \mathrm{~S}$ by Wenk et al. (2013) suggests otherwise. Several modes of fixed nitrogen removal were examined in the water column of an alpine lake. Anammox activities were shown to coincide with sulfide-dependent denitrification and were even enhanced with the addition of $\mathrm{H}_{2} \mathrm{~S}$ in incuba-

environmental conditions, bacterial community structure and activities. Hu et al. (2011) reported a dominance of 'Candidatus Brocadia' and 'Candidatus Kuenenia' in the Qiantang River, China and also demonstrated a positive correlation between sediment organic carbon and anammox bacteria, where organic carbon significantly influences anammox bacterial diversity. Dang et al. (2010) also showed sediment organic material was among the most influential environmental parameters related to the distribution of anammox bacteria in the hypernutrified Jiaozhou Bay, China. The positive correlation of sediment \%organics with anammox activities and abundance, in particular to Jettenia-like organisms, might indicate that anammox bacteria can use organic matter as an electron donor or carbon source. This proposal is supported by previous studies where anammox bacteria were able to anaerobically remove ammonia in the presence of organic matter in bioreactors (Güven et al. 2005, Sabumon 2007). The ability of anammox bacteria to use organic acids, such as acetate and propionate, as supplementary carbon sources has been demonstrated in 'Candidatus Kuenenia stuttgartiensis', tions. It has been suggested that $\mathrm{NH}_{4}{ }^{+}$for the anammox process may be provided by sulfate $\left(\mathrm{SO}_{4}{ }^{2-}\right)$ reduction coupled to organic matter oxidation, as was observed in Chilean waters where an active coupling of the sulfur and nitrogen cycles was observed in a $\mathrm{NO}_{3}{ }^{-}$-rich, oxygen-free zone (Canfield et al. 2010). This coupling was proposed to generate up to $22 \%$ of the $\mathrm{NH}_{4}{ }^{+}$necessary to support observed activities of anammox in this oxygen-depleted system.

Although not explicitly examined in this study, anammox communities in the NRE may be supported through remineralization of organic matter by sulfate-reducing communities in these sulfide-rich sediments. Elevated levels of $\mathrm{H}_{2} \mathrm{~S}$ were observed in the mesohaline reaches of the estuary at the mid-estuary stations, concurring with a rich supply of sediment $\%$ organics and higher potential activities. A coupling between anammox and other nitrogen cycling processes, in particular denitrification and dissimilatory nitrate reduction to ammonia (DNRA), might also explain the correlation between anammox activities, $\mathrm{H}_{2} \mathrm{~S}$ and \%organics. Under the incubation conditions used in this study, intermediates produced during 
heterotrophic denitrification driven by carbon availability or chemolithotrophic denitrification by $\mathrm{H}_{2} \mathrm{~S}$ observed in some aquatic systems (Cardoso et al. 2006) may provide the substrate that supports anammox via $\mathrm{NO}_{2}{ }^{-}$production. Likewise, $\mathrm{H}_{2} \mathrm{~S}$ or organic matter could provide reducing power for the reduction of $\mathrm{NO}_{3}{ }^{-}$to $\mathrm{NH}_{4}{ }^{+}$via DNRA and would also cause a dependency of anammox on another respiratory processes for substrate. This dependency of anammox on denitrification or DNRA for substrate might be driving the observed correlation of anammox with \%organics and $\mathrm{H}_{2} \mathrm{~S}$ observed in the NRE.

The positive correlation between denitrification and porewater $\mathrm{H}_{2} \mathrm{~S}$ still suggests that a coupling between the nitrogen and sulfur cycles might exist in the NRE, as denitrifying bacteria are capable of using reduced sulfur species as electron donors for the reduction of $\mathrm{NO}_{3}^{-}$. Given the fact that anammox activities were observed in the presence of high levels of $\mathrm{H}_{2} \mathrm{~S}$ and organic matter, the results suggest that these environmental parameters do not inhibit anammox or denitrification as previously thought. Furthermore, DNRA is an important mechanism for retaining $\mathrm{N}$ within saline systems, such as estuaries (Koike \& Hattori 1978, Tobias et al. 2001, Giblin et al. 2013) and it may be of interest in future studies to examine the relationship between DNRA and anammox in estuarine sediments.

Studies of anammox bacterial communities in estuarine sediments generally report the dominance of Scalindua-like organisms, as described in Chesapeake Bay, USA (Rich et al. 2008), Yodo River Estuary, Japan (Amano et al. 2007), Jiaozhou Bay, China (Dang et al. 2010) and the Cape Fear River Estuary, USA (Dale et al. 2009, Hirsch et al. 2011). While Scalindua-like groups were detected in the lower reaches of the NRE, 'Candidatus Scalindua spp.' were not the dominant anammox bacteria in the NRE. Jettenia-like anammox dominated $71 \%$ of the clones obtained seasonally throughout the NRE. This is the first time that an estuarine environment was shown to have a dominance of Jettenia-like anammox. Previous studies of anammox activity measurements in batch incubations containing 'Candidatus Brocadia anammoxidans' or 'Candidatus Kuenenia stuttgartiensis' resulted in activities 4 times higher than 'Candidatus Scalindua spp.' enrichments under similar conditions (Schmid et al. 2003). The presence of 'Candidatus Jettenia spp.' and the increase in activities at M15 coinciding with the shift away from 'Candidatus Scalindua spp.' at this site may provide some evidence to support the differences in nitrogen removal efficiency of anammox groups in a natural system. This notion may have implications for nitrate removal in estuaries that tend to favor one group over another, particularly in organic-rich, high-nutrient systems such as the NRE.

Finally, as mentioned earlier, a degree of meteorological forcing has been shown to govern biological activities in estuarine systems (Peierls et al. 2012). In this study, a dramatic increase of freshwater discharge during the winter sampling event supported bottom-up effects on anammox communities in the NRE. During this freshening event, anammox community structure in the downstream site M15 shifted to closely resemble upstream areas of the estuary. Two possible mechanisms may be responsible for this occurrence: the advection of upstream anammox organisms to the lower estuary or changes in environmental conditions as a result of the long-term freshening of the estuary throughout the winter enabled small populations of 'Candidatus Jettenia spp.' anammox to become dominant. It is still unclear how to determine whether dispersal or environmental conditions affect composition of microbial communities due to the covariance of changing environmental conditions during rainfall events responsible for advection of microbes (Crump et al. 2007). Thus, the species-sorting perspective can be used to provide an explanation for the presence and dominance of 'Candidatus Jettenia spp.' throughout the NRE. The species-sorting perspective emphasizes the control of environmental conditions on community structure and dispersal (Leibold et al. 2004, Crump et al. 2007). This is important because it sets the community from which the dominant assemblage will develop. In the case of the NRE, 'Candidatus Jettenia spp.' may have been transported throughout the estuary and favorable environmental conditions allowed for the proliferation of the bacteria. Increased substrate availability and a shift in community structure allowed for higher anammox activity at this site and further support the linkage between environmental parameters, anammox community composition and activities in an estuarine system.

\section{CONCLUSIONS}

Anammox and denitrification activities were detected throughout the 7 sites during all seasons and denitrification was the dominant $\mathrm{N}_{2}$-producing pathway in the NRE. Anammox contributed up to $14 \%$ of total $\mathrm{N}_{2}$ production and activities were positively correlated with abundance of the hzo genes, both of which were positively correlated with porewater $\mathrm{H}_{2} \mathrm{~S}$ 
concentrations and \%organics. These correlations can be explained by the ability of anammox bacteria to use organic material as a carbon substrate or through the coupling of the nitrogen, sulfur and carbon cycles. Phylogenetic analysis of hzo sequences revealed that Jettenia-like organisms were dominant throughout the NRE. A freshening of the estuary during the winter distributed upstream anammox communities to downstream sites and increased anammox activities. This study provides evidence that an episodic flushing event may have influenced the widespread distribution of Jettenia-like organisms, and together with the geochemical conditions of the system governed anammox bacterial community structure and activities in this temperate estuarine ecosystem.

Acknowledgements. Funding for this research was provided by the US National Science Foundation (DEB1020944) and NSF-OCE (0851435). The authors thank L. B. Cahoon, M. A. Mallin, R. Whitehead and S. Borrett for their contributions to this study. The authors also thank The Song, Tobias and Borrett Laboratories, in particular M. Lettrich, R. Young and A. Arfken, as well as M. Mclever and the Aquatic Ecology Laboratory for assistance in seasonal sampling and processing. Finally, the authors thank M. Hanke and D. E. Hines for providing help with manuscript figures and data analysis as well as I. C. Anderson, D. A. Bronk and B. B. Ward for providing comments and feedback on this manuscript. This paper is Contribution No. 3329 of the Virginia Institute of Marine Science, College of William and Mary.

\section{LITERATURE CITED}

Amano T, Yoshinaga I, Okada K, Yamagishi T and others (2007) Detection of anammox activity and diversity of anammox bacteria-related 16S rRNA genes in coastal marine sediment in Japan. Microbes Environ 22:232-242

Amano T, Yoshinaga I, Yamagishi T, Van Thuoc C and others (2011) Contribution of anammox bacteria to benthic nitrogen cycling in a mangrove forest and shrimp ponds, Haiphong, Vietnam. Microbes Environ 26:1-6

Anderson IC, Brush MJ, Piehler MF, Currin CA and others (2013) Impacts of climate-related drivers on the benthic nutrient filter in a shallow photic estuary. Estuar Coast, doi:10.1007/s12237-013-9665-5

- Braman RS, Hendrix SA (1989) Nanogram nitrite and nitrate detection in environmental and biological materials by vanadium(III) chemiluminescence detection. Anal Chem 61:2715-2718

- Burkholder JM, Mallin MA, Glasgow HB Jr, Larsen LM and others (1997) Impacts to a coastal river and estuary from rupture of a large swine waste holding lagoon. J Environ Qual 26:1451-1466

Canfield DE, Stewart FJ, Thamdrup B, De Brabandere L and others (2010) A cryptic sulfur cycle in oxygen-minimumzone waters off the Chilean coast. Science 330: $1375-1378$
Cardoso RB, Sierra-Alvarez R, Rowlette P, Field JA, Flores ER, Go J (2006) Sulfide oxidation under chemolithoautotrophic denitrifying conditions. Biotechnol Bioeng 95: 1148-1157

> Cline J (1969) Spectrophotometric determination of hydrogen sulfide in natural waters. Limnol Oceanogr 14: 454-458

> Cornwell JC, Kemp WM, Kana TM (1999) Denitrification in coastal ecosystems: methods, environmental controls, and ecosystem level controls, a review. Aquat Ecol 33: 41-54

Costanza R, d'Arge R, de Groot R, Farber S and others (1997) The value of the world's ecosystem services and natural capital. Nature 387:253-260

> Crump BC, Hopkinson CS, Sogin ML, Hobbie JE (2004) Microbial biogeography along an estuarine salinity gradient : combined influences of bacterial growth and residence time. Appl Environ Microbiol 70:1494-1505

> Crump RC, Adams HE, Hobbie JE, Kling GW (2007) Biogeography of bacterioplankton in lakes and streams of an Arctic tundra catchment. Ecology 88:1365-1378

> Dafner EV, Mallin MA, Souza JJ, Wells HA, Parsons DC (2007) Nitrogen and phosphorus species in the coastal and shelf waters of Southeastern North Carolina, MidAtlantic U.S. coast. Mar Chem 103:289-303

Dale OR, Tobias CR, Song B (2009) Biogeographical distribution of diverse anaerobic ammonium oxidizing (anammox) bacteria in Cape Fear River Estuary. Environ Microbiol 11:1194-1207

> Dalsgaard T, Canfield DE, Petersen J, Thamdrup B, AcuñaGonzález J (2003) N2 production by the anammox reaction in the anoxic water column of Golfo Dulce, Costa Rica. Nature 422:606-608

- Dalsgaard T, Thamdrup B, Canfield DE (2005) Anaerobic ammonium oxidation (anammox) in the marine environment. Res Microbiol 156:457-464

> Dame R, Alber M, Allen D, Mallin M and others (2000) Nitrogen and phosphorus species in the coastal and shelf waters of Southeastern North Carolina, Mid-Atlantic U.S. coast. Estuaries 23:793-819

> Dang H, Chen R, Wang L, Guo L and others (2010) Environmental factors shape sediment anammox bacterial communities in hypernutrified Jiaozhou Bay, China. Appl Environ Microbiol 76:7036-7047

> Engström P, Dalsgaard T, Hulth S, Aller RC (2005) Anaerobic ammonium oxidation by nitrite (anammox): implications for $\mathrm{N}_{2}$ production in coastal marine sediments. Geochim Cosmochim Acta 69:2057-2065

Ensign SH, Doyle MW (2006) Nutrient spiraling in streams and river networks. J Geophys Res 111:G04009, doi: 10.1029/2005JG000114

Ensign SH, Halls JN, Mallin MA (2004) Application of digital bathymetry data in an analysis of flushing times of two large estuaries. Comput Geosci 30:501-511

Giblin A, Tobias CR, Song B, Weston N, Banta GT, Rivera-Monroy VH (2013) The importance of dissimilatory nitrate reduction to ammonium (DNRA) in the nitrogen cycle of coastal ecosystems. Oceanography 26:124-131

> Güven D, Dapena A, Kartal B, Schmid MC and others (2005) Propionate oxidation by and methanol inhibition of anaerobic ammonium-oxidizing bacteria. Appl Environ Microbiol 71:1066-1071

Hall NS, Paerl HW, Peierls BL, Whipple AC, Rossignol KL (2013) Effects of climatic variability on phytoplankton 
community structure and bloom development in the eutrophic, New River Estuary, North Carolina, USA. Estuar Coast Shelf Sci 117:70-82

Hannig M, Lavik G, Kuypers M, Woebken D, MartensHabbena W, Jurgens K (2007) Shift from denitrification to anammox after inflow events in the central Baltic Sea. Limnol Oceanogr 52:1336-1345

- Hietanen S, Kuparinen J (2007) Seasonal and short-term variation in denitrification and anammox at a coastal station on the Gulf of Finland, Baltic Sea. Hydrobiologia 596:67-77

> Hirsch MD, Long ZT, Song B (2011) Anammox bacterial diversity in various aquatic ecosystems based on the detection of hydrazine oxidase genes (hzoA/hzoB). Microb Ecol 61:264-276

> Hong YG, Li M, Cao H, Gu JD (2011) Residence of habitatspecific anammox bacteria in the deep-sea subsurface sediments of the South China Sea: analyses of marker gene abundance with physical chemical parameters. Microb Ecol 62:36-47

Howarth R, Anderson D, Cloern J (2000) Nutrient pollution of coastal rivers, bays, and seas. Issues Ecol 7:1-17

> Hu BI, Rush D, van der Biezen E, Zheng P and others (2011) New anaerobic, ammonium-oxidizing community enriched from peat soil. Appl Environ Microbiol 77: 966-971

> Jensen MM, Kuypers MMM, Lavik G, Thamdrup B (2008) Rates and regulation of anaerobic ammonium oxidation and denitrification in the Black Sea. Limnol Oceanogr 53: 23-36

Kana T, Sullivan M, Cornwell J, Groszkowski K (1998) Denitrification in estuarine sediments determined by membrane inlet mass spectrometry. Limnol Oceanogr 43: 334-339

Kartal B, Keltjens JT, Jetten MS (2008) The metabolism of anammox. eLS, doi: 10.1002/9780470015902.a0021315

Koike I, Hattori A (1978) Denitrification and ammonia formation in anaerobic coastal sediments. Appl Environ Microbiol 35:278-282

Koop-Jakobsen K, Giblin AE (2009) Anammox in tidal marsh sediments: the role of salinity, nitrogen loading, and marsh vegetation. Estuar Coast 32:238-245

Leibold MA, Holyoak M, Mouquet N, Amarasekare P and others (2004) The metacommunity concept: a framework for multi-scale community ecology. Ecol Lett 7:601-613

Li M, Hong Y, Klotz MG, Gu JD (2010) A comparison of primer sets for detecting 16S rRNA and hydrazine oxidoreductase genes of anaerobic ammonium-oxidizing bacteria in marine sediments. Appl Microbiol Biotechnol 86:781-790

Long SE, Martin T (1997) Method for the determination of chemical substances in marine and estuarine environmental matrices, 2nd edn. US Environmental Protection Agency, National Service for Environmental Publications, Washington, DC

> Long A, Heitman J, Tobias C, Philips R, Song B (2013) Cooccurring anammox, denitrification, and codenitrification in agricultural soils. Appl Environ Microbiol 79: 168-176

> Lozupone C, Knight R (2005) UniFrac: a new phylogenetic method for comparing microbial communities. Appl Environ Microbiol 71:8228-8235

> Mackin JE, Aller RC (1984) Ammonium adsorption in marine sediments. Limnol Oceanogr 29:250-257

Mallin MA, Burkholder JM, Cahoon LB, Posey MH (2000)
North and South Carolina coasts. Mar Pollut Bull 41: 56-75

Mallin MA, McIver MR, Wells HA, Parsons DC, Johnson VL (2005) Reversal of eutrophication following sewage treatment upgrades in the New River Estuary, North Carolina. Estuaries 28:750-760

> Meyer RL, Risgaard-Petersen N, Allen DE (2005) Correlation between anammox activity and microscale distribution of nitrite in a subtropical mangrove sediment. Appl Environ Microbiol 71:6142-6149

Minjeaud L, Michotey VD, Garcia N, Bonin PC (2009) Seasonal variation in di-nitrogen fluxes and associated processes (denitrification, anammox and nitrogen fixation) in sediment subject to shellfish farming influences. Aquat Sci 71:425-435

Nicholls JC, Trimmer M (2009) Widespread occurrence of the anammox reaction in estuarine sediments. Aquat Microb Ecol 55:105-113

Nixon S (1995) Coastal marine eutrophication: a definition, social causes, and future concerns. Ophelia 41:199-219

Peierls BL, Hall NS, Paerl HW (2012) Non-monotonic responses of phytoplankton biomass accumulation to hydrologic variability: a comparison of two coastal plain North Carolina estuaries. Estuar Coast 35:1376-1392

> Quan ZX, Rhee SK, Zuo JE, Yang Y and others (2008) Diversity of ammonium-oxidizing bacteria in a granular sludge anaerobic ammonium-oxidizing (anammox) reactor. Environ Microbiol 10:3130-3139

Rich JJ, Dale OR, Song B, Ward BB (2008) Anaerobic ammonium oxidation (anammox) in Chesapeake Bay sediments. Microb Ecol 55:311-320

Risgaard-Petersen N, Meyer R (2004) Anaerobic ammonium oxidation in an estuarine sediment. Aquat Microb Ecol 36:293-304

Rysgaard S, Glud RN, Risgaard-Petersen N, Dalsgaard T (2004) Denitrification and anammox activity in Arctic marine sediments. Limnol Oceanogr 49:1493-1502

Sabumon PC (2007) Anaerobic ammonia removal in presence of organic matter: a novel route. J Hazard Mater 149:49-59

Schmid M, Walsh K, Webb R, Rijpstra WIC and others (2003) Candidatus 'Scalindua brodae', sp. nov., Candidatus 'Scalindua wagneri', sp. nov., two new species of anaerobic ammonium oxidizing bacteria. Syst Appl Microbiol 26:529-538

Schmid MC, Hooper AB, Klotz MG, Woebken D and others (2008) Environmental detection of octahaem cytochrome $c$ hydroxylamine/hydrazine oxidoreductase genes of aerobic and anaerobic ammonium-oxidizing bacteria. Environ Microbiol 10:3140-3149

Seitzinger S, Harrison JA, Böhlke JK, Bouwman AF and others (2006) Denitrification across landscapes and waterscapes: a synthesis. Ecol Appl 16:2064-2090

Song B, Tobias CR (2011) Molecular and stable isotope methods to detect and measure anaerobic ammonium oxidation (anammox) in aquatic ecosystems. In: Methods in enzymology, 1st edn. Elsevier, Burlington, MA, p 63-89

> Stookey LL (1970) Ferrozine-a new spectrophotometric reagent for iron. Anal Chem 42:779-781

Strous M, Pelletier E, Mangenot S, Rattei T and others (2006) Deciphering the evolution and metabolism of an anammox bacterium from a community genome. Nature 440 : 790-794

Tal Y, Watts JEM, Schreier HJ (2005) Anaerobic ammoniaoxidizing bacteria and related activity in Baltimore 
inner harbor sediment. Appl Environ Microbiol 71: 1816-1821

Thamdrup B, Dalsgaard T (2002) Production of $\mathrm{N}_{2}$ through anaerobic ammonium oxidation coupled to nitrate reduction in marine sediments. Appl Environ Microbiol 68: 1312-1318

Tobias CR, Anderson IC, Canuel EA, Macko SA (2001) Nitrogen cycling through a fringing marsh-aquifer ecotone. Mar Ecol Prog Ser 210:25-39

Trimmer M, Nicholls JC, Deflandre B (2003) Anaerobic ammonium oxidation measured in sediments along the Thames Estuary, United Kingdom. Appl Environ Microbiol 69:6447-6454

Trimmer M, Nicholls JC, Morley N, Davies CA, Aldridge J (2005) Biphasic behavior of anammox regulated by nitrite and nitrate in an estuarine sediment. Appl Environ Microbiol 71:1923-1930

Tuominen L, Heinanen A, Kuparinen J, Nielsen LP (1998) Spatial and temporal variability of denitrification in the sediments of the northern Baltic Proper. Mar Ecol Prog
Ser 172:13-24

van de Graaf AA, Mulder A, de Bruijn P, Jetten MS, Robertson LA, Kuenen JG (1995) Anaerobic oxidation of ammonium is a biologically mediated process. Appl Environ Microbiol 61:1246-1251

Wenk CB, Blees J, Zopfi J, Veronesi M and others (2013) Anaerobic ammonium oxidation (anammox) bacteria and sulfide-dependent denitrifiers coexist in the water column of a meromictic south-alpine lake. Limnol Oceanogr 58:1-12

Whitney D, Darley W (1979) A method for the determination of chlorophyll $a$ in samples containing degradation products. Limnol Oceanogr 24:183-186

Zhang Y, Ruan XH, Op den Camp HJM, Smits TJM, Jetten MSM, Schmid MC (2007) Diversity and abundance of aerobic and anaerobic ammonium-oxidizing bacteria in freshwater sediments of the Xinyi River (China). Environ Microbiol 9:2375-2382

Zumft WG (1997) Cell biology and molecular basis of denitrification. Microbiol Mol Biol Rev 61:533-616

Appendix 1. Potential activities and gene abundance for dentrification and anammox in the New River Estuary. All values are mean $\pm \mathrm{SE}$

Table A1. Potential $\mathrm{N}_{2}$ production by (a) denitrification and (b) anammox and (c) percent anammox calculated from ${ }^{15} \mathrm{~N}$ isotope pairing experiments on sediment slurry incubations

\begin{tabular}{|lcccc|}
\hline \multicolumn{5}{|c|}{ (a) Denitrification $\left(\mathrm{nmol}^{30} \mathrm{~N}_{2} \mathrm{~g}^{-1}\right.$ wet sediment $\mathrm{h}^{-1}$ ) } \\
Site & Jun & Sep & Dec & Apr \\
\hline AA2 & $4.29 \pm 0.43$ & $11.43 \pm 0.07$ & $5.06 \pm 0.10$ & $4.66 \pm 0.11$ \\
Jax & $9.92 \pm 0.91$ & $6.14 \pm 4.10$ & $16.20 \pm 2.12$ & $12.13 \pm 0.95$ \\
M53 & $7.27 \pm 0.30$ & $1.79 \pm 0.06$ & $14.13 \pm 0.15$ & $30.98 \pm 3.00$ \\
M47 & $9.91 \pm 3.00$ & $3.37 \pm 0.45$ & $0.89 \pm 0.20$ & $9.37 \pm 0.31$ \\
M39 & $4.63 \pm 1.35$ & $3.40 \pm 0.47$ & $16.08 \pm 0.74$ & $21.29 \pm 7.11$ \\
M31 & $3.10 \pm 0.01$ & $4.15 \pm 0.03$ & $11.21 \pm 1.67$ & $5.41 \pm 0.27$ \\
M15 & $0.45 \pm 0.05$ & $2.16 \pm 0.27$ & $1.77 \pm 0.13$ & $0.36 \pm 0.10$ \\
b) Anammox (nmol ${ }^{29} \mathrm{~N}_{2} \mathrm{~g}^{-1}$ wet sediment $\left.\mathrm{h}^{-1}\right)$ \\
Site & Jun & \multicolumn{4}{c}{ Sep } \\
\hline \multirow{5}{*}{ AA2 } & $0.35 \pm 0.02$ & $0.86 \pm 0.03$ & $0.55 \pm 0.00$ & $0.76 \pm 0.05$ \\
Jax & $0.80 \pm 0.09$ & $0.26 \pm 0.17$ & $0.89 \pm 0.14$ & $1.05 \pm 0.18$ \\
M53 & $0.48 \pm 0.00$ & $0.07 \pm 0.00$ & $0.70 \pm 0.06$ & $1.40 \pm 0.41$ \\
M47 & $0.68 \pm .016$ & $0.08 \pm 0.01$ & $0.02 \pm 0.00$ & $0.61 \pm 0.03$ \\
M39 & $0.15 \pm 0.05$ & $0.07 \pm 0.01$ & $0.55 \pm 0.10$ & $0.50 \pm 0.22$ \\
M31 & $0.08 \pm 0.00$ & $0.07 \pm 0.00$ & $0.42 \pm 0.08$ & $0.31 \pm 0.02$ \\
M15 & $0.03 \pm 0.00$ & $0.10 \pm 0.01$ & $0.11 \pm 0.01$ & $0.02 \pm 0.00$ \\
\hline
\end{tabular}

\begin{tabular}{|lcccr|}
\hline \multicolumn{4}{l}{ (c) \%anammox } \\
Site & Jun & Sep & Dec & Apr \\
\hline AA2 & $7.61 \pm 0.23$ & $7.02 \pm 0.18$ & $9.78 \pm 0.20$ & $14.08 \pm 1.01$ \\
Jax & $7.43 \pm 0.13$ & $4.11 \pm 0.07$ & $5.20 \pm 0.13$ & $7.96 \pm 0.65$ \\
M53 & $6.16 \pm 0.20$ & $3.91 \pm 0.04$ & $4.74 \pm 0.37$ & $4.29 \pm 0.81$ \\
M47 & $6.51 \pm 0.41$ & $2.26 \pm 0.01$ & $1.98 \pm 0.38$ & $6.11 \pm 0.07$ \\
M39 & $3.10 \pm 0.14$ & $2.14 \pm 0.02$ & $3.30 \pm 0.41$ & $2.27 \pm 0.24$ \\
M31 & $2.49 \pm 0.04$ & $1.66 \pm 0.01$ & $3.62 \pm 0.10$ & $5.41 \pm 0.12$ \\
M15 & $7.26 \pm 0.19$ & $4.41 \pm 0.06$ & $4.75 \pm 0.30$ & $6.29 \pm 1.34$
\end{tabular}

Table A2. Abundance of anammox bacteria in New River Estuary sediments determined by hzo gene quantitative PCR

\begin{tabular}{|lcc|}
\hline Site & \multicolumn{2}{c|}{$\begin{array}{c}\text { Jzo mean copy number } \mathrm{g}^{-1} \text { sediment } \\
\text { Dec }\end{array}$} \\
\hline AA2 & $2.40 \mathrm{E}+05 \pm 7.12 \mathrm{E}+04$ & $6.75 \mathrm{E}+04 \pm 1.17 \mathrm{E}+04$ \\
Jax & $2.54 \mathrm{E}+05 \pm 5.64 \mathrm{E}+04$ & $2.09 \mathrm{E}+05 \pm 3.27 \mathrm{E}+04$ \\
M53 & $1.20 \mathrm{E}+05 \pm 1.56 \mathrm{E}+04$ & $1.69 \mathrm{E}+05 \pm 7.46 \mathrm{E}+04$ \\
M47 & $2.45 \mathrm{E}+05 \pm 7.85 \mathrm{E}+04$ & $1.92 \mathrm{E}+05 \pm 3.32 \mathrm{E}+04$ \\
M39 & $2.59 \mathrm{E}+05 \pm 9.30 \mathrm{E}+04$ & $2.16 \mathrm{E}+05 \pm 3.61 \mathrm{E}+04$ \\
M31 & $1.22 \mathrm{E}+05 \pm 6.10 \mathrm{E}+04$ & $2.42 \mathrm{E}+05 \pm 6.65 \mathrm{E}+03$ \\
M15 & $1.55 \mathrm{E}+02 \pm 2.94 \mathrm{E}+00$ & $7.48 \mathrm{E}+02 \pm 3.43 \mathrm{E}+03$ \\
\hline
\end{tabular}

Editorial responsibility: Patricia Glibert, Cambridge, Maryland, USA
Submitted: July 9, 2013; Accepted: December 17, 2013 Proofs received from author(s): February 20, 2014 